Progress in

Physical Geography

\title{
Vegetation structure influences the retention of airfall tephra in a sub-Arctic landscape
}

\begin{tabular}{|c|c|}
\hline Journal: & Progress in Physical Geography \\
\hline Manuscript ID & PPG-15-094.R1 \\
\hline Manuscript Type: & Main Article \\
\hline Keywords: & $\begin{array}{l}\text { aeolian sediment, tephrochronology, Iceland, photogrammetric analysis, } \\
\text { vegetation structure }\end{array}$ \\
\hline Abstract: & $\begin{array}{l}\text { Vegetation cover mediates a number of important geomorphological } \\
\text { processes. However, the effect of different vegetation types on the } \\
\text { retention of fine aeolian sediment is poorly understood. We investigated } \\
\text { this phenomenon, using the retention of fine, pyroclastic material (tephra) } \\
\text { from the } 2011 \text { eruption of the Grímsvötn volcano, Iceland, as a case study. } \\
\text { We set out to quantify structural variation in different vegetation types and } \\
\text { to relate structural metrics to the thickness of recently deposited volcanic } \\
\text { ash layers in the sedimentary section. We utilised a combination of } \\
\text { vegetation and soil surveys, along with photogrammetric analysis of } \\
\text { vegetation structure. We found that indices of plant community } \\
\text { composition were a poor proxy for vegetation structure and were largely } \\
\text { unrelated to tephra thickness. However, structural metrics, derived from } \\
\text { photogrammetric analysis, were clearly related to variations in tephra layer } \\
\text { thickness at a landscape scale and tephra layers under shrub patches were } \\
\text { significantly thicker than those outside the shrub canopy. We therefore } \\
\text { concluded that a) vegetation cover was a critical factor in the retention of } \\
\text { fine aeolian sediment for deposit depths up to few centimetres and b) } \\
\text { structural variation in vegetation cover played a major role in determining } \\
\text { the configuration of tephra deposits in the sedimentary section. These } \\
\text { findings have implications for the analysis of ancient volcanic eruptions and } \\
\text { archaeological/palaeoenvironmental reconstructions based on the } \\
\text { interpretation of tephra deposits. Furthermore, they present the possibility } \\
\text { that the detailed form of tephra layers may be used as a proxy for palaeo } \\
\text { vegetation structure. }\end{array}$ \\
\hline
\end{tabular}

\section{SCHOLARONE $^{\text {"x }}$ \\ Manuscripts}




\section{Abstract}

2 Vegetation cover mediates a number of important geomorphological processes.

3 However, the effect of different vegetation types on the retention of fine aeolian

4 sediment is poorly understood. We investigated this phenomenon, using the retention

5 of fine, pyroclastic material (tephra) from the 2011 eruption of the Grímsvötn volcano,

6 Iceland, as a case study. We set out to quantify structural variation in different

7 vegetation types and to relate structural metrics to the thickness of recently deposited

8 volcanic ash layers in the sedimentary section. We utilised a combination of vegetation

9 and soil surveys, along with photogrammetric analysis of vegetation structure. We

10 found that indices of plant community composition were a poor proxy for vegetation

11 structure and were largely unrelated to tephra thickness. However, structural metrics,

12 derived from photogrammetric analysis, were clearly related to variations in tephra

13 layer thickness at a landscape scale and tephra layers under shrub patches were

14 significantly thicker than those outside the shrub canopy. We therefore concluded that

15 a) vegetation cover was a critical factor in the retention of fine aeolian sediment for

16 deposit depths up to few centimetres and b) structural variation in vegetation cover

17 played a major role in determining the configuration of tephra deposits in the

18 sedimentary section. These findings have implications for the analysis of ancient

19 volcanic eruptions and archaeological/palaeoenvironmental reconstructions based on

20 the interpretation of tephra deposits. Furthermore, they present the possibility that the

21 detailed form of tephra layers may be used as a proxy for palaeo vegetation structure.

\section{Keywords}

25 Aeolian sediment, tephrochronology, Iceland, photogrammetric analysis, vegetation

26 structure 
Introduction

30 Vegetation cover is a key factor in terrestrial geomorphology, as it mediates

31 microclimate, hydrological processes and mass movement (Marston, 2010). Vegetation

32 plays a particularly important role in the entrapment and stabilisation of sediment

33 carried by fluids, whether the fluid is water (e.g. salt marshes) or air (e.g. sand dunes)

34 (see, e.g., Baas, 2002; Langlois et al., 2003). However, the precise impact of different

35 vegetation types on terrestrial sediment cycles is still poorly understood. For example,

36 volcanoes produce considerable quantities of airborne ash and this material is a major

37 component of soils worldwide (Takahashi and Shoji, 2002). However, the processes by

38 which fine, pyroclastic particles (tephra) are trapped and incorporated into soils are not

39 well defined. In contrast to the quasi-continuous aeolian deposition typical of arid or

40 coastal environments, tephra are typically deposited rapidly, ballistically and in discrete

events (often separated by many years), so the rules that govern other forms of

42 sediment accumulation may not be strictly applicable. Vegetation cover is likely to play

43 a role in the retention of tephra, but the importance of this factor has not been explored.

44 The overall aim of this research was therefore to investigate how different vegetation

45 types influence the retention of episodically deposited aeolian sediment, using the

46 deposition of volcanic ash as an exemplar.

47

48

49 Previous work has indicated that the capacity of vegetation to trap and retain sediment

50 is dependent upon its structure (the physical configuration of above ground biomass

51 and the intervening voids: Zehm et al., 2003) and the way in which this structure

52 modifies local wind fields (e.g. structural configurations which greatly reduce wind

53 speeds are likely to result in sediment retention). Many different metrics of vegetation

54 structure have been proposed; however, previous studies have demonstrated that the

55 ability of vegetation to trap sediment is captured by relatively straightforward

56 characteristics e.g. vegetation height, density and porosity (i.e. the network of voids 
defined by stems, leaves, etc. within the vegetation: Moller, 2006). Whilst these aggregate characteristics are conceptually simple, they are difficult to measure reliably in the field. The most promising techniques for investigating vegetation structure have involved photogrammetry i.e. the quantitative analysis of high-resolution photographic images. Surveys utilising this technique have demonstrated that photogrammetric studies of vegetation can be rapid, detailed, reproducible and, under ideal circumstances, non-destructive (Moller, 2006; Neumeier, 2005; Zehm et al., 2003). Consequently, we set out to refine existing photogrammetric techniques in order to capture the essential structural characteristics of low-growing vegetation (mosses, forbs and short graminoids), structural types that have been neglected by previous 67 researchers.

68

69

Our study focused on the deposition and retention of airfall tephra. Tephra particles are pyroclastic fragments produced during explosive volcanic eruptions (Lowe, 2011; Thorarinsson, 1944). Coarse tephra grains (lapilli with a diameter $>\sim 4 \mathrm{~mm}$ ) are rapidly sedimented from the atmosphere and are mostly confined to a region proximal to the volcano. However, fine grains may be transported considerable distances (100s to $1000 \mathrm{~s} \mathrm{~km}$ ) in the atmosphere before they are deposited as airfall tephra (Stevenson et al., 2015). Once on the ground, they are readily mobilised by wind and water unless something acts to stabilise them (Sarna-Wojcicki et al., 1981). If the tephra deposit is stabilised and of sufficient thickness it can form clearly defined layers in sedimentary sections. These layers cover large parts of Earth's surface. Tephra deposits are of interest for three main reasons. Firstly, they may be used in the reconstruction of the fallout area and erupted volume of past volcanic eruptions (Lowe, 2011). When conducting reconstructions of this type, it is essential to know how faithfully the tephra layer records the characteristics of the initial deposit. This is particularly important in spatially extensive distal locations where the quantity of tephra is greatest (see, e.g., Sarna-Wojcicki et al., 1981), but the deposit is thin, fine-grained and readily 
86 transformed. Secondly, tephra layers are frequently used as chronostratigraphic

87 horizons (Lowe, 2011). In this case, all that matters is the identification of the isochron.

88 Thirdly, if a tephra layer is considered to be a pulse of sediment of known age and 89 provenance, it may be used as a tracer to understand a) geomorphological processes

90 that are otherwise impractical to investigate e.g. aeolian erosion and deposition and b)

91 the environmental impacts of an eruption, using palaeoecological techniques.

92

93

94 The interpretation of tephra layers in the soil is premised on the assumption that the 95 thickness of the layer in the soil is directly related to the thickness of the initial deposit. 96 Airfall tephra mantles the landscape, i.e. the thickness of a fresh deposit is likely to be 97 more-or-less the same in locations separated by a few kilometres, unless such 98 locations are near the edge of the plume. However, tephra layers in the sedimentary 99 section are often highly variable over small spatial scales (centimetres - metres)

100 (Streeter and Dugmore, 2013b). If ancient tephra layers are to be correctly interpreted, 101 it is necessary to understand the processes by which a fresh tephra deposit is 102 ultimately transformed into a sedimentary layer. Thick tephra deposits (tens of $\mathrm{cm}-$ 103 metres thick) obliterate vegetation cover and geomorphological processes are likely to 104 determine the overall configuration of the final deposit. However, there is evidence that 105 some vegetation can survive moderate (up to a few $\mathrm{cms}$ ) tephra deposition. Some 106 mosses, for example, are porous to fine tephra particles and can absorb light falls 107 without detrimental effects. Bjarnason (1991) reported that carpets of the moss 108 Racomitrium lanuginosum can absorb falls of up to $8 \mathrm{~cm}$ without incurring significant 109 damage; Zobel \& Antos (1997) noted moss recovery from falls < 2cm in forest adjacent 110 to Mount St. Helens and Hotes et al (2004) reported the recovery of Sphagnum spp. 111 moss from beneath deposits $6 \mathrm{~cm}$ thick. It is therefore possible that surviving biomass 112 can trap and stabilise tephra, thus influencing the formation of tephra layers (Streeter 113 and Dugmore, 2013a). 
116 A number of studies have investigated the impact of tephra deposition on vegetation

117 cover (see, e.g., Kent et al., 2001; Arnalds, 2013a). However, few have considered the

118 problem in reverse. This project investigated the relationship between vegetation

119 structure and tephra depth on a series of sites in southern Iceland. Tephra-producing

120 volcanic eruptions occur on average every 3 years in Iceland and the tephrochronology

121 of the island is well constrained (Haflidason et al., 2000; Thordarson and Larsen, 2007;

122 Larsen et al., 1999). It is therefore an ideal location for a study of this type. Our specific

123 research aims were to 1 ) assess the utility of plant community composition as a proxy

124 for vegetation structure; 2) establish whether qualitatively different types of vegetation

125 cover, defined largely on the basis of species composition, could be differentiated using

126 photogrammetric analysis of structure and 3) relate metrics of vegetation structure to

127 the thickness of recently deposited tephra layers in the sedimentary section.

128

129

130

Methods

131

132

Sampling locations

133 The research was conducted on three sites in southern Iceland: Fossdalur, Kalfafell

134 and Blómsturvellir (Fig. 1). The Kalfafell site provided two sampling locations (one

135 dominated by moss and one by grass), giving four sampling locations in total (Table 1).

136 Tephra were deposited on the sites during the 2011 eruption of the Grímsvötn volcano

137 (hereafter referred to as G2011). The G2011 eruption produced $\sim 0.6-0.8 \mathrm{~km} 3$ of

138 tephra which were subsequently distributed over a large area of southern Iceland

139 (Gudmundsson et al., 2012). All of the study sites were located between 50-55 km from

140 Grímsvötn caldera and within the main axis of fallout from the eruption (Fig. 1e). The

141 initial depth of the tephra deposit was similar on all the sampling locations. By the time

142 the surveys were conducted (June 2014) the G2011 tephra was not visible on the

143 surface, either because the vegetation had grown through tephra and/or the particles 
144 had percolated through the vegetation. Rather, the G2011 tephra formed a distinct,

145 dark layer in the upper horizons of the soil. Three years of post-eruption deposition had

146 led to a layer of sediment $0.25-1.5 \mathrm{~mm}$ thick on top of the tephra, deposition rates in

147 line with measures of accumulation in southern Iceland over the past 100 years

148 (Streeter and Dugmore, 2013a).

151 The sampling locations were broadly flat or gently sloping and had limited

152 microtopographic variation (Fig. 1). The key characteristic that varied between the

153 sampling locations was vegetation cover, which was categorised qualitatively at the

154 beginning of the study, based on the dominant functional type of vegetation. The major

155 growth forms encountered were mosses, graminoids and dwarf shrubs. With the

156 exception of the Blómsturvellir sampling location (where the moss/graminoid heath was

157 interrupted by small shrub patches) we deliberately chose sampling locations with

158 relatively homogeneous vegetation cover.

159

160 Table 1: Site characteristics

161

162 Fig. 1: Site photos

163

164

165

Vegetation surveys

166 The vegetation cover on each of the four sampling locations was recorded using

167 systematic quadrat surveys (Table 1). A $50 \times 50 \mathrm{~cm}$ quadrat was deployed on a grid;

168 the grid dimensions varied according to the size and shape of each sampling location.

169 We recorded all of the plant species present and estimated the cover of each taxon

170 according to the Domin scale (Kent, 2012). The survey encompassed both mosses and

171 vascular plants. The survey was conducted in June 2014; the 2011 tephra was

172 deposited in March, so the vegetation at the time would have been relatively less 
173 developed. However, the relative change in vegetation density between seasons is low 174 in Iceland and we therefore assumed that the vegetation surveys would give us an 175 indication of the relative differences between vegetation types.

176

177

178 The Blómsturvellir site, which was characterised by patches of woolly willow (Salix

179 lanata) in a matrix of grass/moss heath, was initially surveyed using a grid of quadrats

180 (the Bg survey). This survey mainly covered the low-growing vegetation (predominantly 181 composed of mosses and graminoids). Ground-layer vegetation under the shrub 182 patches was then surveyed using haphazardly-placed quadrats (the Bh survey, $\mathrm{N}=$ 183 20), to see if the presence of a willow canopy impacted on the graminoid/bryophyte 184 community.

185

186

187 Photogrammetric surveys

188 The survey technique applied was based on that developed by Zehm et al. (2003) and 189 subsequently refined by others (Moller, 2006; Neumeier, 2005). A side-on, high190 resolution digital photograph was taken of a patch of vegetation $35 \mathrm{~cm}$ across $\times 25 \mathrm{~cm}$ 191 deep (Fig. 2). A $35 \mathrm{~cm}$ wide $\times 27 \mathrm{~cm}$ high white backing board was placed behind the 192 target vegetation. The camera was positioned on a line normal to the centre of the 193 board, at a distance of $80 \mathrm{~cm}$. The vegetation immediately adjacent to the target zone 194 was removed by excavation: this made the ground line visible and permitted high195 resolution measurements of the underlying tephra layer. The remaining vegetation 196 between the camera and the target zone was flattened with a board, so that it did not 197 appear in the photograph. 198 199 Fig. 2: cartoon of camera set-up

200 201 
202 Tephra depth

203 The G2011 layer exposed in the excavated area was measured at five points at 12.5

$204 \mathrm{~cm}$ intervals (i.e. at both ends of the exposed section and at three points in between).

205 The tephra layer was identified on the basis of colour (black, in contrast to the orange-

206 brown andisol). Measurements of tephra thickness were made to the nearest

207 millimetre.

208

209

210 Photographic image processing

211 The raw digital images were converted to grayscale and cropped to the boundaries of

212 the backing board, using the programme Adobe Photoshop ${ }^{\mathrm{TM}}$. Each image was then

213 processed using a bespoke routine written in MATLAB. First, the grayscale images

214 were converted to black and white images using a threshold parameter that was

215 adjusted according to camera exposure and vegetation type to ensure correspondence

216 between pixel colour and true plant presence/absence. Starting from the base of each

217 image and working upwards, the routine counted the numbers of black pixels

218 (vegetation) in each row of the image, thereby encapsulating the vertical structure of

219 the vegetation. From these data, it was straightforward to calculate the overall density

220 of the vegetation i.e. the proportion of black pixels and the maximum height of the

221 vegetation. However, these simple metrics are likely miss some of the complexity of the

222 vegetation structure e.g., where maximum height is driven by a single, slender leaf that

223 extends above the bulk of the vegetation. Consequently, the programme was designed

224 to return more detailed structural metrics. For example, vegetation density (proportion

225 of black pixels) at any given height may be calculated. It is also possible to derive more

226 nuanced metrics of vertical vegetation structure e.g. the height below which a given

227 proportion of black pixels occur $\left(\mathrm{P}_{\mathrm{x}}\right.$, where $\mathrm{x}$ is proportion of the total number of pixels).

228 If $\mathrm{P}_{\mathrm{x}}$ is plotted against height, vegetation cover with different structural configurations

229 would be expected to produce qualitatively different curves (Fig. 3).

230 
Figs 3: Hypothetical analyses of vegetation structure

232

233

234

Analysis

235 Detrended correspondence analysis (DCA) was applied to the vegetation survey data.

236 DCA is a robust multivariate technique that is capable of dealing with noisy data (ter

237 Braak, 1995). DCA was used to graphically represent the different vegetation

238 communities and to establish whether a) the initial, qualitative assessments of

239 vegetation type were supported by quantitative analysis of community composition and

240 b) how similar the ground layer vegetation under the willow canopy on the

241 Blómsturvellir site was to the surrounding, unshaded vegetation. DCA was also used to

242 calculate the compositional variability of the plant communities, expressed in terms of

243 multivariate inertia, a unitless metric of variability that is analogous to variance. If

244 community composition is a good proxy for vegetation structure and vegetation

245 structure influences tephra depth, then compositional variability should be correlated

246 with variation in the tephra thickness. Shannon diversity was also calculated as a

247 metric of compositional variability.

248

249

250 Photogrammetry was used to describe vegetation structure at each sampling location.

251 The MATLAB routine was used to calculate the cumulative proportion of black pixels

252 (P) with height for each quadrat. The distributions were then modelled for each

253 sampling location by fitting a curve of the form $y=a\left(1-e^{-b x}\right)$, which represents a

254 gradual attenuation of vegetation density with height (Fig. 3). This two-parameter

255 function was chosen as it provides sound fits and also contains parameters which are

256 intuitively helpful: a rate $(b)$ describing the change in density with height, and an

257 asymptote (a) describing the total vegetation density of the image (i.e. the curvature of

258 the fitted line). The significance of the fit was established using Monte Carlo

259 techniques. 
260

261

262

263

264

265

266

267

268

269

270

271

272

273

274

275

276

277

278

279

280

281

282

283

284

285

286

Mean tephra thicknesses on each site were analysed using ANOVA and the sites compared using a post hoc test (Tukey's HSD). We also calculated the coefficient of variation (CV) of tephra layer thickness for each sampling location, so this figure could be compared with variability in plant community composition. We assessed the relationship between vegetation structure and tephra thickness using a linear mixed effects model, with mean G2011 thickness in each quadrat as the response variable, vegetation height (derived from the photogrammetric analysis) as the fixed effect and site identity as the random effect. The variables were log-transformed prior to the analysis, which was conducted using the Ime4 package in $\mathrm{R}$ (Bates et al., 2015). The significance of the model was assessed by comparing it to a null model (i.e. omitting the fixed effect) using ANOVA (Bolker et al., 2009).

We assumed that the extant plant community was a good analogue for vegetation cover at the time of the eruption as a) the initial tephra deposits were thin (previous work has estimated the critical deposit thickness for abrupt vegetation change in Iceland at $20 \mathrm{~cm}$ : Arnalds, 2013b) and b) Icelandic vegetation is very resilient and previous observations have shown how thin tephra deposits may percolate through the ground layer without disrupting plant growth (Bjarnason, 1991). The sampling locations were close to cultivated areas, but were not artificially cleared of G2011 tephra. The sites were visited by the authors immediately after the 2011 eruption, and annually thereafter: there was no evidence that vegetation had changed markedly post-G2011.

\section{Results}


287 Vegetation surveys

288 The distribution of the quadrats in ordination space broadly matched the qualitative 289 assessments of vegetation type. Quadrats on the left hand side of the DCA biplot (Fig.

290 4a) could be characterised as grass-dominated vegetation (note the position of 291 common grasses Festuca sp. and Agrostis sp. in relation to the quadrats from $\mathrm{Kg}$ and 292 B). Those on the right hand side were moss-dominated: all the dominant moss species 293 (Racomitrium lanuginosum, R. ericoides, Hylocomium splendens) were on this side, 294 with the exception of Rhytidiadelphus squarrosus, a common moss often found in 295 grass sward. The Fossdalur quadrats spanned both regions.

296

297

298 The DCA also indicated that the sampling locations differed in terms of their

299 compositional variability (Fig. 4a). The $\mathrm{F}$ and $\mathrm{Km}$ sites were the most variable in terms

300 of community composition, based on the distribution of quadrats in ordination space

301 and multivariate inertia (Table 2). In contrast, the $\mathrm{Kg}$ and B sites were tightly clustered

302 and largely overlapping. On the Blómsturvellir site, there appeared to be no substantial

303 difference between the vegetation under the willow canopy and the plant communities 304 between the willow patches (Fig. 4b).

305

306

Fig. 4: DCA biplot

307

308 Table 2: Metrics of variability

309

310 Models of vegetation structure

311 The exponential curve selected was a good fit for the data (Fig. 5): adjusted $R^{2}$ values

312 were all above 0.95 , and the model parameters were highly significant in all cases $(p<$ 313 0.001). The initial part of the fitted curve was clearly steeper on the mossy sites ( $F$ and $314 \mathrm{Km})$. On the grassy sites ( $\mathrm{Kg}$ and $\mathrm{B}$ ), the curve was flatter (note the lower values of $b$ : 
315 Fig. 5). Mean vegetation height, represented in this case by the height below which

$31670 \%$ of vegetation occurred (U0.7) was markedly higher on the grassy sites.

317

318 Fig. 5: modelled curves for each sampling location

319

320

321

Vegetation structure and tephra depth

322

Mean tephra depth varied significantly according to site location (ANOVA: $F_{4,61}=42.1$,

323 $p<0.001$ ), even though the initial deposit depth was similar (Olsson et al., 2013). The tephra layer in the Bh survey (i.e. under the willow canopy) was significantly thicker than the G2011 layers in the other surveys; conversely, the layer on the Km site was significantly thinner (Fig. 6). There was no significant difference in the thickness of the tephra layers on the $\mathrm{F}, \mathrm{Kg}$ and $\mathrm{Bg}$ sites.

328

329

330

U0.7 figures were used to express vegetation height in each quadrat. Maximum

331 vegetation height (U1.0) could have been used, but this figure is sensitive to the presence of isolated stems and may be unrepresentative of overall vegetation structure. At the scale of each sampling location, the relationship between vegetation height and tephra thickness was unclear. However, at a landscape scale, tephra thickness increased with vegetation height in a broadly hyperbolic fashion (Fig. 7). A linear mixed effects model of the log-transformed data indicated a significant positive relationship $\left(x^{2}(1)=8.46, p=0.004\right)$.

338

339

Fig. 6: Box plots indicating G2011 tephra thickness in each sampling location. 340

341 Fig. 7: The relationship between vegetation height (U0.7) and G2011 thickness on the 342 sites. 
Discussion

346

347 Vegetation composition

348 The results of the DCA were consistent with the qualitative assessments of vegetation

349 types that were made during site selection. The sampling locations could be broadly

350 divided into 'mossy' locations $(\mathrm{Km})$ and 'grassy' locations $(\mathrm{Kg}, \mathrm{B})$, with Fossdalur

351 occupying an intermediate position. The mossy sites were more variable, in terms of

352 species composition and abundance, than the grassy sites. The apparent variability of

353 the Km site was largely driven by the inclusion of a handful of quadrats that

354 encompassed very different surface cover (i.e. two quadrats on totally eroded surfaces

355 and several on boggy ground, located in the upper right quarter of Fig. 4a). When these

356 quadrats were excluded, the $\mathrm{Km}$ location was less variable. Even allowing for this site-

357 specific factor, a thick grass sward is likely to exclude colonisation by other plants and

358 the hence suppress botanical diversity, so it was not unsurprising that the grassy sites

359 were less variable.

360

361

362 If plant communities do influence tephra layer thickness, then one could hypothesise

363 that variability in the plant community would be related to variability in the thickness of

364 the G2011 tephra layer. Following from this, we had hoped that plant community

365 composition would be a surrogate for vegetation structure. However, the relationship

366 between community variability (Shannon diversity, multivariate inertia) and variability in

367 the G2011 tephra layer was weak. Whilst plant community composition and vegetation

368 structure are related on a fundamental level, within-species variation in growth form is

369 likely to obscure this relationship. Furthermore, many species present in the plant

370 community will make minimal contributions to the structural factors relevant for tephra

371 stabilisation, whilst other species will dominate. For example, a single shrub species

372 drove major changes in tephra depth on the Blómsturvellir site. It is possible that plant 
373 traits related to structural features might be more useful predictors than species identity

374 and this topic could be the focus of a future study. Without this information, the generic

375 structural properties identified by the photogrammetric surveys appear to be much

376 more informative than metrics of plant community composition.

377

378

379 Ultimately, the relationship between plant community composition and tephra thickness

380 will depend on the spatial scale at which the wind responds to variation in vegetation

381 form. For example, the scale of turbulence in the wind is large compared to individual

382 plants, then a relationship between plant community composition and tephra thickness

383 would not necessarily be expected. Put another way, small-scale, plant-to-plant

384 variation might not have any effect on the deposition or stabilisation of tephra. If this

385 model applies, then the most meaningful vegetation data to collect would relate to

386 structural properties averaged over a certain distance. We speculate that the key

387 distance is larger than our quadrat size, but smaller than the quadrat spacing. Further

388 spatial analysis based on transect measurements will be required to establish this.

389

390

391 Differentiating sampling locations on the basis of structural characteristics

392 The models of vegetation structure derived from the photogrammetry captured

393 qualitative differences between the sampling locations. On the $\mathrm{Km}$ site (dominated by a

394 dense layer of the pleurocarpous moss, $R$. lanuginosum), the vegetation was clearly

395 concentrated close to the ground. On sites dominated by graminoids, tall, erect stems

396 meant that the vegetation was more evenly distributed over a range of heights,

397 approximating the straight line plot in Fig. 3 (indicated by the lower values of $b$ on the

398 grassy sites). It was therefore possible to distinguish between the sampling locations in

399 a physically meaningful way without explicitly referring to species identity. This finding

400 has implications for the generalisation of our results to other locations.

401 
403 Survey methods other than photogrammetry could have been applied. For example, a

404 pin-touch technique could have been used for conducting high-resolution surveys of

405 vegetation height. However, this technique is relatively slow to apply in the field and

406 records just one variable. In contrast, we found the photogrammetric approach to be

407 relatively quick and the resulting data set rich and versatile.

408

409

410 Vegetation structure and tephra thickness

411 Our study strongly suggested that vegetation structure is a key factor in determining

412 the thickness of the tephra layer preserved in the sedimentary section. This relationship

413 is strongest at a landscape scale, i.e. between sampling locations. The relationship

414 was less clear within sites (10s of $\mathrm{m}$ ). At a site scale, variability in vegetation structure

415 was limited as we chose sites with relatively homogeneous cover and noise (generated

416 by unmeasured or essentially random processes) most likely obscured clear

417 relationships. Higher resolution sampling of the vegetation may resolve this issue, as

418 there was a mismatch between the scale of the vegetation metric (quadrat scale) and

419 the tephra measurements (sub-quadrat scale).

420

421

422 At a larger scale, where the variation in vegetation structure was greater, a positive 423 correlation suggestive of a deterministic relationship emerged. This was probably 424 because the large scale analyses included vegetation types at different ends of the 425 continuum of vegetation types (moss vs tall grass and, in the case of Bh, dwarf 426 shrubs). The relationship appeared to be non-linear. No G2011 tephra was observed 427 on sites without vegetation cover i.e. the eroded sites within the $\mathrm{Km}$ sampling location. 428 Presumably, fresh tephra on these denuded surfaces is readily eroded. When 429 vegetation cover was low, small increases in vegetation height appeared to have a 430 major impact on the thickness of tephra in the soil. In taller vegetation, height increases 
431 of the same magnitude have a smaller (but still broadly positive) effect, leading to 432 hyperbolic relationship (Fig. 7). The analysis of tephra thickness on the Blómsturvellir 433 site reinforced the impression that vegetation cover plays a major role in determining 434 tephra depth. The tephra layers in patches of Salix lanata were significantly thicker 435 than those under the surrounding, low-growing vegetation (Fig. 6), even though the 436 plants in the ground layer were essentially the same.

437

438 This study focussed on aboveground vegetation structure as the major agent mediating 439 tephra layer thickness. However, other factors also likely to be significant. Antecedent 440 moisture levels, for example, are likely to change the 'stickiness' of newly deposited 441 tephra. Plant traits that influence the way that moisture is retained on leaves and stems 442 could therefore work alongside the morphological aspects of vegetation cover.

443 Belowground structure might also be significant e.g. the particularly dense root

444 structures associated with tussocky graminoids could influence the incorporation of 445 tephra into the soil (although we did not observe this effect during out study).

446

447

448 Implications of research

449 Our findings have clear implications for the interpretation of tephra layers. For the 450 purposes of volcanic reconstruction, it is usually assumed that airfall tephra deposits do 451 not undergo modification, unless they are very thick, in which case slope processes 452 may come into play. However, our research shows that vegetation cover is likely to be 453 important, too, particularly on smaller spatial scales and where the initial deposit depth 454 is not so great that plant cover is extirpated. This finding offers the tantalising possibility 455 that, under certain circumstances, variability in tephra layer thickness across a site may 456 be used as a proxy for the vegetation cover extant at the time of the eruption (in terms 457 of structure, if not taxonomy). This finding is especially important for the calculation of 458 past eruptive volumes if vegetation cover may have varied significantly through time. If 459 vegetation was significantly taller at the time of eruption, calculations of eruption 
460 volume may be over-estimated. Furthermore, assessing variation in multiple, well461 dated tephra layers may give insight into the spatio-temporal dynamics of vegetation 462 cover over long time periods (Streeter and Dugmore, 2013a).

463

464

\section{Conclusions}

466 Our research shows that the thickness of a recent tephra layer was correlated with the

467 vegetation structure present at the time of deposition. We found that plant community

468 composition was a poor surrogate for the physical structure of vegetation cover.

469 However, photogrammetric analysis proved to be an effective way of capturing relevant

470 structural characteristics. Analyses using this technique demonstrated that vegetation

471 cover on different sites could be differentiated according to generic structural

472 properties. These findings have implications for the interpretation of tephra layers,

473 whether this work involves the analysis of ancient volcanic eruptions or

474 archaeological/palaeoenvironmental reconstructions. Furthermore, it is possible that

475 small-scale variability in tephra layers, rather than being interpreted as unhelpful

476 'noise', could be used as a proxy for palaeo vegetation structure. 


\section{References}

479

480

481

482

483

484

485

486

487

488

489

490

491

492

493

494

495

496

497

498

499

500

501

502

503

504

505

506

507

508

509

510

511

512

513

514

515

516

517

518
Arnalds O. (2013a) The Influence of Volcanic Tephra (Ash) on Ecosystems. In: Sparks DL (ed) Advances in Agronomy, Vol 121. 331-380.

Arnalds O. (2013b) The Influence of Volcanic Tephra (Ash) on Ecosystems. In: Sparks DL (ed) Advances in Agronomy, Vol 121. 331-380.

Baas ACW. (2002) Chaos, fractals and self-organization in coastal geomorphology: simulating dune landscapes in vegetated environments. Geomorphology 48: 309-328.

Bates D, Maechler M, Bolker B, et al. (2015) Fitting linear mixed-effects models using Ime4. Journal of Statistical Software 67: 1-48.

Bjarnason ÁH. (1991) Vegetation on lava fields in the Hekla area, Iceland, Uppsala: Acta Phytogeographica Suecica.

Bolker BM, Brooks ME, Clark CJ, et al. (2009) Generalized linear mixed models: a practical guide for ecology and evolution. Trends in Ecology \& Evolution 24: 127-135.

Gudmundsson MT, Höskuldsson Á, Larsen G, et al. (2012) The May 2011 eruption of Grímsvötn. EGU General Assembly. Vienna, Austria: Copernicus.

Haflidason H, Eiriksson J and Van Kreveld S. (2000) The tephrochronology of Iceland and the North Atlantic region during the Middle and Late Quaternary: a review. Journal of Quaternary Science 15: 3-22.

Hotes S, Poschlod P, Takahashi H, et al. (2004) Effects of tephra deposition on mire vegetation: a field experiment in Hokkaido, Japan. Journal of Ecology 92: 624634.

Kent M. (2012) Vegetation description and data analysis, Chichester: Wiley-Blackwell.

Kent M, Owen NW, Dale P, et al. (2001) Studies of vegetation burial: a focus for biogeography and biogeomorphology? Progress in Physical Geography 25: 455 $-482$.

Langlois E, Bonis A and Bouzille JB. (2003) Sediment and plant dynamics in saltmarshes pioneer zone: Puccinellia maritima as a key species? Estuarine Coastal and Shelf Science 56: 239-249.

Larsen G, Dugmore A and Newton A. (1999) Geochemistry of historical-age silicic tephras in Iceland. Holocene 9: 463-471.

Lowe DJ. (2011) Tephrochronology and its application: A review. Quaternary Geochronology 6: 107-153.

Marston RA. (2010) Geomorphology and vegetation on hillslopes: Interactions, dependencies, and feedback loops. Geomorphology 116: 206-217.

Moller I. (2006) Quantifying saltmarsh vegetation and its effect on wave height dissipation: Results from a UK East coast saltmarsh. Estuarine Coastal and Shelf Science 69: 337-351.

Neumeier U. (2005) Quantification of vertical density variations of salt-marsh vegetation. Estuarine Coastal and Shelf Science 63: 489-496. 
Olsson J, Stipp SLS, Dalby KN, et al. (2013) Rapid release of metal salts and nutrients from the 2011 Grímsvötn, Iceland volcanic ash. Geochimica et Cosmochimica Acta 123: 134-149.

Sarna-Wojcicki AM, Shipley S, Waitt RB, et al. (1981) Areal Distribution, Thickness, Mass, Volume, and Grain Size of Air-Fall Ash from the Six Major Eruptions of 1980. In: Lipman PW and Mullineaux DR (eds) The 1980 Eruptions of Mount St. Helens, Washington. Washington D.C.: USGS, 577-600.

Stevenson JA, Millington SC, Beckett FM, et al. (2015) Big grains go far: understanding the discrepancy between tephrochronology and satellite infrared measurements of volcanic ash. Atmospheric Measurement Techniques 8: 2069-2091.

Streeter R and Dugmore AJ. (2013a) Anticipating land surface change. Proceedings of the National Academy of Sciences of the United States of America 110: 57795784.

Streeter RT and Dugmore AJ. (2013b) Reconstructing late-Holocene environmental change in Iceland using high-resolution tephrochronology. Holocene 23: 197207.

Takahashi T and Shoji S. (2002) Distribution and classification of volcanic ash soils. Global Environmental Research 6: 83-98.

ter Braak CJF. (1995) Ordination. In: Jongman RHG, ter Braak CJF and van Tongeren OFR (eds) Data Analysis in Community and Landscape Ecology. Cambridge: Cambridge University Press, 91-173.

Thorarinsson S. (1944) Tefrokronologiska studier på Island. Geografiska Annaler 26: 1217.

Thordarson T and Larsen G. (2007) Volcanism in Iceland in historical time: Volcano types, eruption styles and eruptive history. Journal of Geodynamics 43: 118152.

Zehm A, Nobis M and Schwabe A. (2003) Multiparameter analysis of vertical vegetation structure based on digital image processing. Flora 198: 142-160. 
Figure captions

551

552 Fig. 1: The sampling locations: a) Fossdalur (F); b) the mossy Kalfafell sampling

553 location (Km); c) the grassy Kalfafell sampling location $(\mathrm{Kg})$ and d) Blómsturvellir (B:

554 the lighter patches in the image are the dwarf willow, Salix lanata); e) the survey area.

555

556 Fig. 2: Diagram indicating the set up used for the photogrammetric survey.

557

558 Fig. 3: Hypothetical analyses of different vegetation types (designated $X, Y$ and $Z$ ). The

559 vertical lines in the top three plots are diagrammatic representations of stems, viewed

560 side-on; the height scale is indicative. The graph at the bottom of the image plots the

561 proportion of biomass against height for each vegetation type. Hypothetical vegetation

562 comprising vertical stems of equal height (vegetation type $X$ ) produces a straight line

563 on the plot. Structural configurations where the vegetation thins with height (types $Y$

564 and Z) produce plots of different curvatures.

565

566 Fig. 4: DCA biplots, with each coloured circle indicating a quadrat survey. Plot a) is of

567 all the sampling locations where grid surveys were conducted. The quadrats on the left

568 hand side are broadly 'grassy' in terms of dominant growth form; those on the left are

569 'mossy'. Plot b) illustrates the plant community on the Blómsturvellir site in more detail,

570 comparing the grid survey (solid circles) with the haphazard survey of ground

571 vegetation under willows (open circles). Key to common species: Agr_sp = Agrostis

572 species; Car_sp = Carex sp.; Equ_pal = Equisetum palustre; Fes_sp $=$ Festuca

573 species; Hyl_spl - Hylocomium splendens; Rac_eri = Racomitrium ericoides; Rac_lan

$574=$ Racomitrium lanuginosum; Rhy_squ = Rhytidiadelphus squarrosus .

575

576 Fig 5: Vertical vegetation structure for each sampling location. The points have been

577 fitted with a curve of the form $y=a\left(1-e^{-b x}\right)$. In this case, the value of $a$ (the

578 asymptote) has been fixed at 1 . The top two graphs $(F, K m)$ have moss-dominated 
579 vegetation; those on the bottom have predominantly grassy vegetation cover. The

580 mean height below which $70 \%$ of vegetation structure occurs (U0.7) is indicated on 581 each plot.

582

583 Fig. 6: Box plots showing mean tephra thickness in each sampling location. The 584 thickness from the Bh survey (beneath willow canopy) is included for comparison.

585

586 Fig. 7: The relationship between vegetation height (expressed here as U0.7, or the 587 height below which $70 \%$ of vegetation occurs) and the mean thickness of the G2011 588 tephra layer in each quadrat. Mean values \pm 1 SE are indicated for each site. Key to 589 sites: $\mathrm{Km}$ = Kalfafell (moss-dominated); F = Fossdalur (moss/grass heath); Kg = 590 Kalfafell (grass-dominated); Bg = Blomsturvellir (grass/shrub). 


\begin{tabular}{lcccl} 
Site & Location & $\begin{array}{c}\text { Survey } \\
\text { area }\end{array}$ & $\begin{array}{c}\text { No. } \\
\text { quadrats }\end{array}$ & Vegetation cover \\
\hline Fossdalur (F) & $63.97^{\circ} \mathrm{N}$ & $30 \times 30 \mathrm{~m}$ & 36 at $6 \mathrm{~m}$ & $\begin{array}{l}\text { Moss heath dominated by } \\
17.49^{\circ} \mathrm{W},\end{array}$ \\
& & intervals & $\begin{array}{l}\text { Racomitrium spp. \& Hylocomium } \\
\text { splendens; sparse graminoid cover } \\
\text { (mainly Agrostis sp., Kobresia } \\
\text { myosuroides). }\end{array}$
\end{tabular}

$\begin{array}{lllll}\begin{array}{l}\text { Kalfafell } \\ \text { (moss) }(\mathrm{Km})\end{array} & \begin{array}{l}63.97^{\circ} \mathrm{N} \\ 17.65^{\circ} \mathrm{W}, \\ 185 \mathrm{~m} \text { asl }\end{array} & 35 \times 20 \mathrm{~m} & \begin{array}{l}40 \text { at } 5 \mathrm{~m} \\ \text { intervals }\end{array} & \begin{array}{l}\text { Mainly low-diversity Racomitrium } \\ \text { lanuginosum moss heath, but } \\ \text { encompassing small, denuded } \\ \text { areas and boggy patches. }\end{array} \\ \begin{array}{l}\text { Kalfafell } \\ \text { (grass) }(\mathrm{Kg})\end{array} & \begin{array}{l}63.96^{\circ} \mathrm{N} \\ 17.66^{\circ} \mathrm{W}, \\ 136 \mathrm{~m} \text { asl }\end{array} & 35 \times 10 \mathrm{~m} & \begin{array}{l}24 \text { at } 5 \mathrm{~m} \\ \text { intervals }\end{array} & \begin{array}{l}\text { Dense grass sward dominated by } \\ \text { Agrostis sp. }\end{array} \\ \begin{array}{l}\text { Blómsturvellir } \\ \text { (B) }\end{array} & \begin{array}{l}63.97^{\circ} \mathrm{N} \\ 17.65^{\circ} \mathrm{W}, \\ 96 \mathrm{~m} \text { asl }\end{array} & 30 \times 18 \mathrm{~m} & \begin{array}{l}24 \text { at } 6 \mathrm{~m} \\ \text { intervals }\end{array} & \begin{array}{l}\text { Boggy ground characterised by } \\ \text { mixture of grass (primarily Festuca } \\ \text { sp., Carex spp.) and moss } \\ \text { (Hylocomium splendens, }\end{array} \\ & & & \begin{array}{l}\text { Rhytidiadelphus squarrosus) heath } \\ \text { with patches of Salix lanata. }\end{array}\end{array}$

2

3 Table 1: Details of sampling locations. 


\begin{tabular}{lccc} 
Site & $\begin{array}{c}\text { Shannon } \\
\text { diversity, } H\end{array}$ & $\begin{array}{c}\text { Multivariate } \\
\text { inertia }\end{array}$ & CV of G2011 \\
\hline Fossdalur & $1.23 \pm 0.46$ & 2.37 & 0.22 \\
Kalfafell (moss) & $0.64 \pm 0.44$ & 2.08 & 0.37 \\
Kalfafell (grass) & $1.44 \pm 0.21$ & 0.52 & 0.19 \\
Blómsturvellir (grid) & $1.59 \pm 0.27$ & 1.70 & 0.25 \\
\hline
\end{tabular}

2

3 Table 2: Metrics of plant community diversity and variability in tephra layer depth (CV = 4 coefficient of variation). Refer to Fig. 6 for mean tephra depths on each site. 
a)

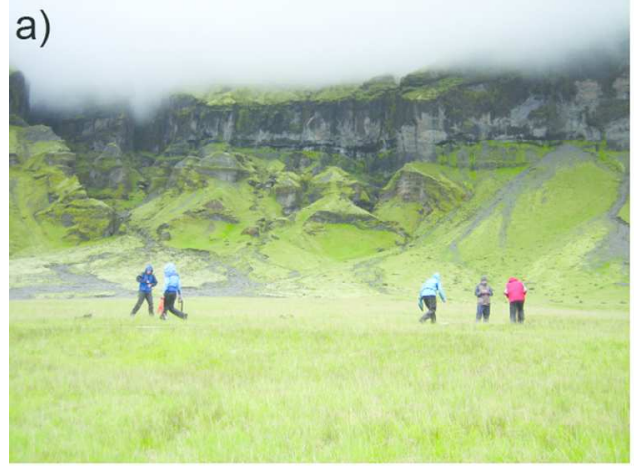

c)

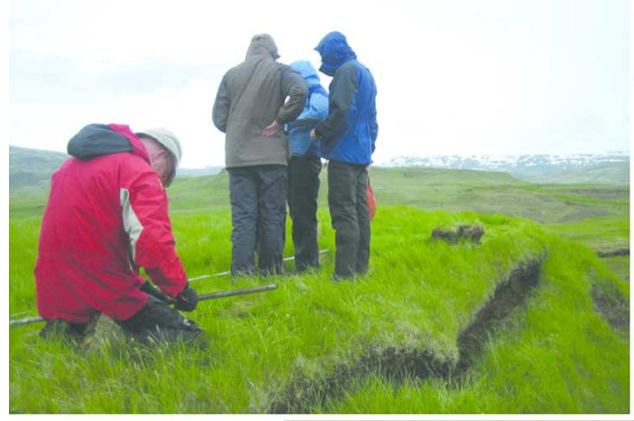

b)

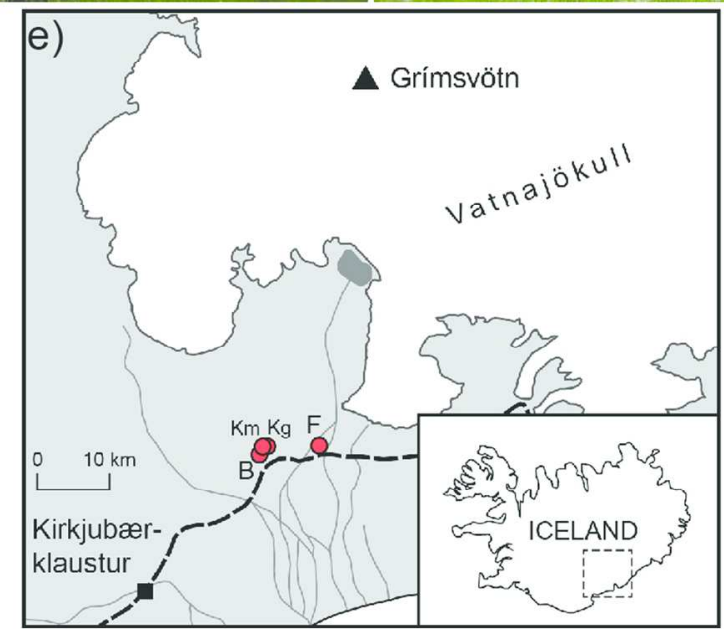

$107 \times 134 \mathrm{~mm}(300 \times 300$ DPI $)$ d)

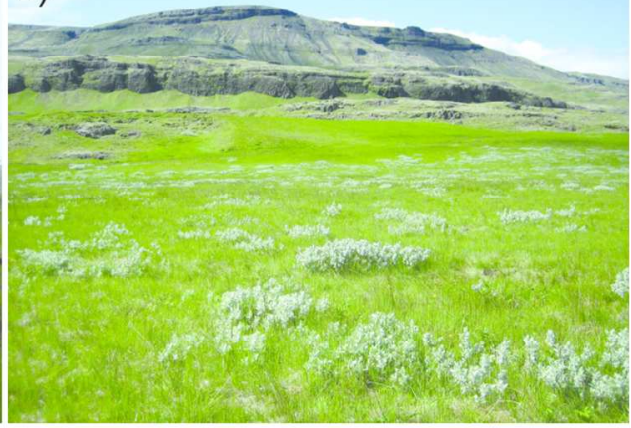




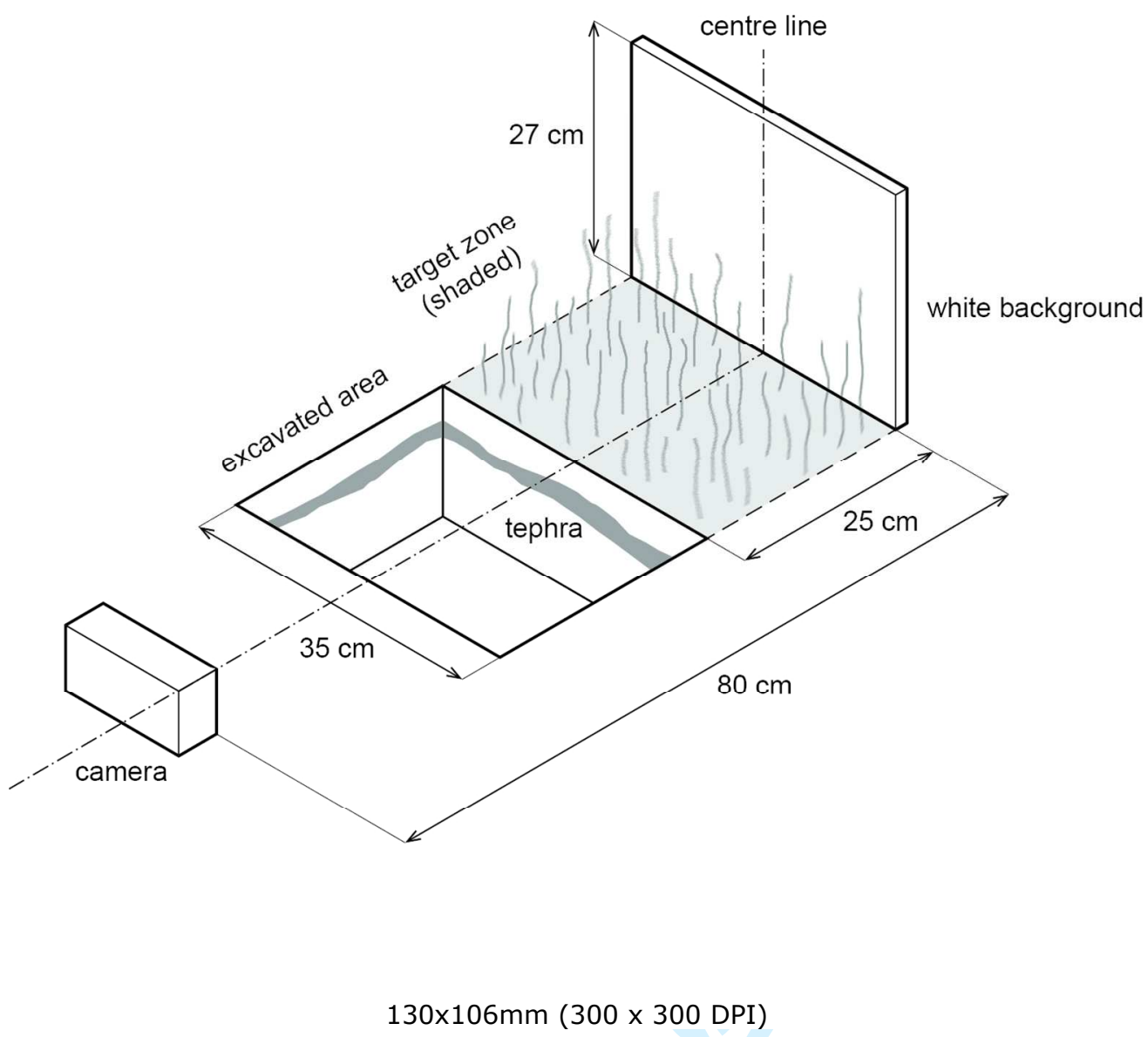



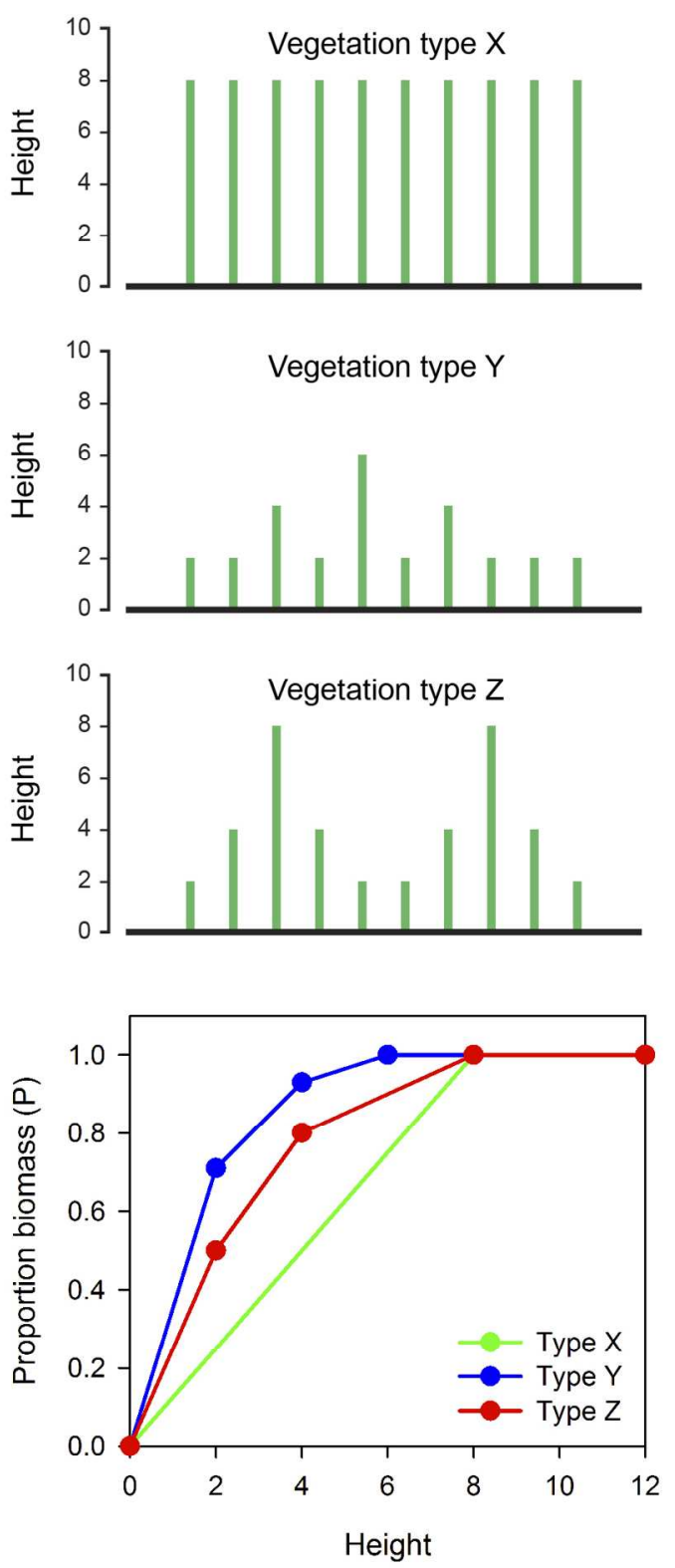

$82 \times 180 \mathrm{~mm}(300 \times 300$ DPI $)$

http://mc.manuscriptcentral.com/PiPG 

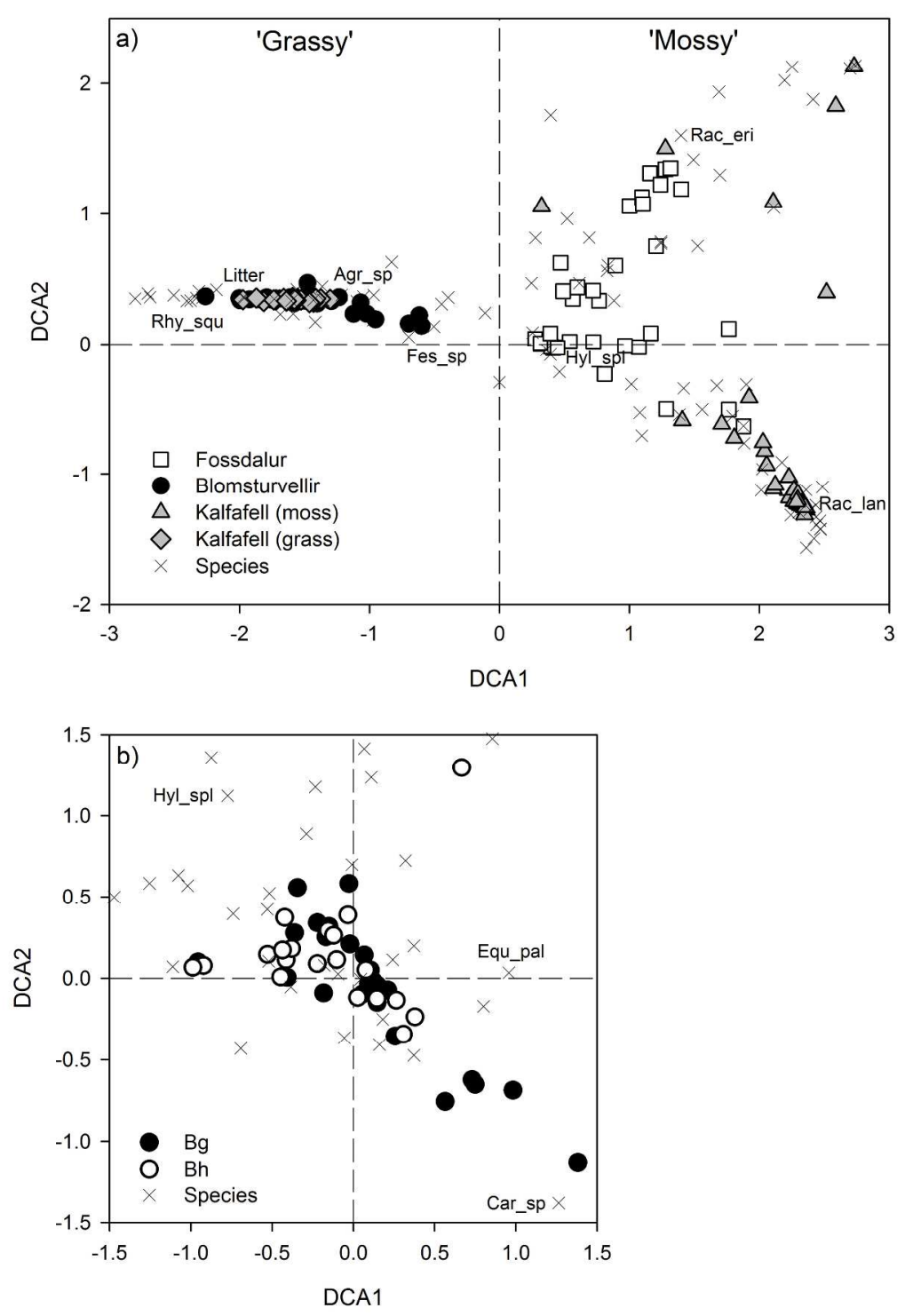

$212 \times 315 \mathrm{~mm}(300 \times 300$ DPI) 

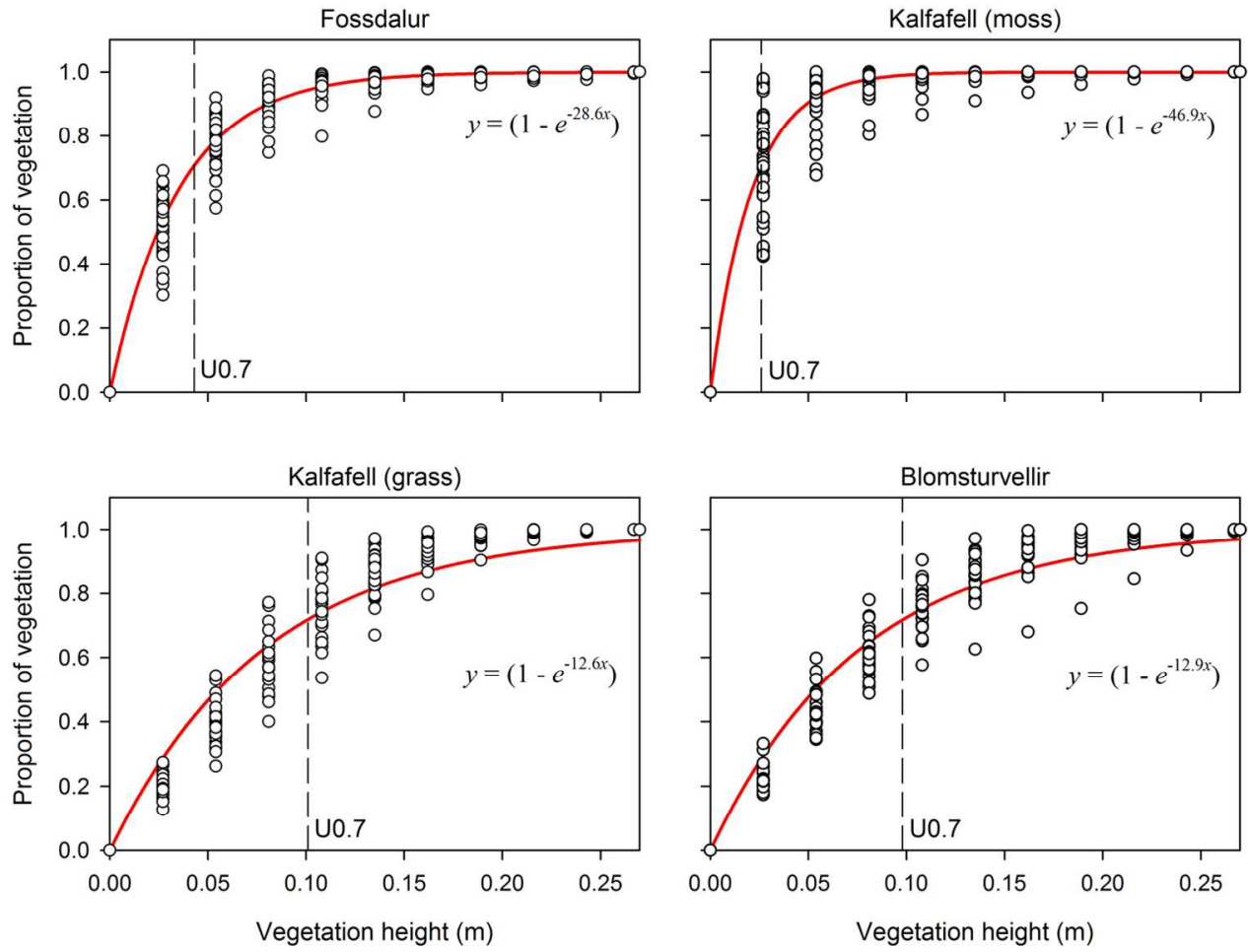

$135 \times 101 \mathrm{~mm}(300 \times 300 \mathrm{DPI})$ 


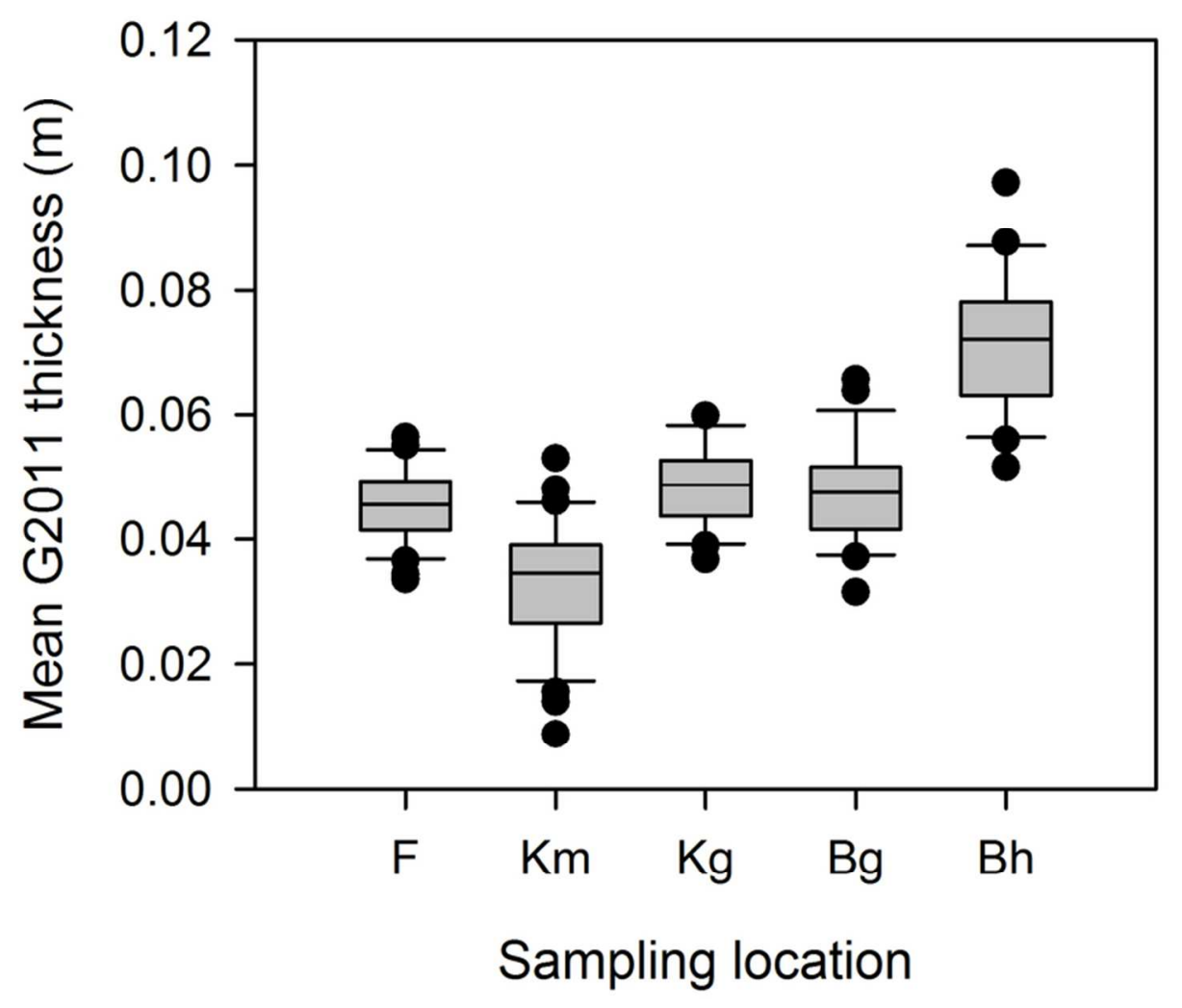

$76 \times 70 \mathrm{~mm}(300 \times 300$ DPI) 


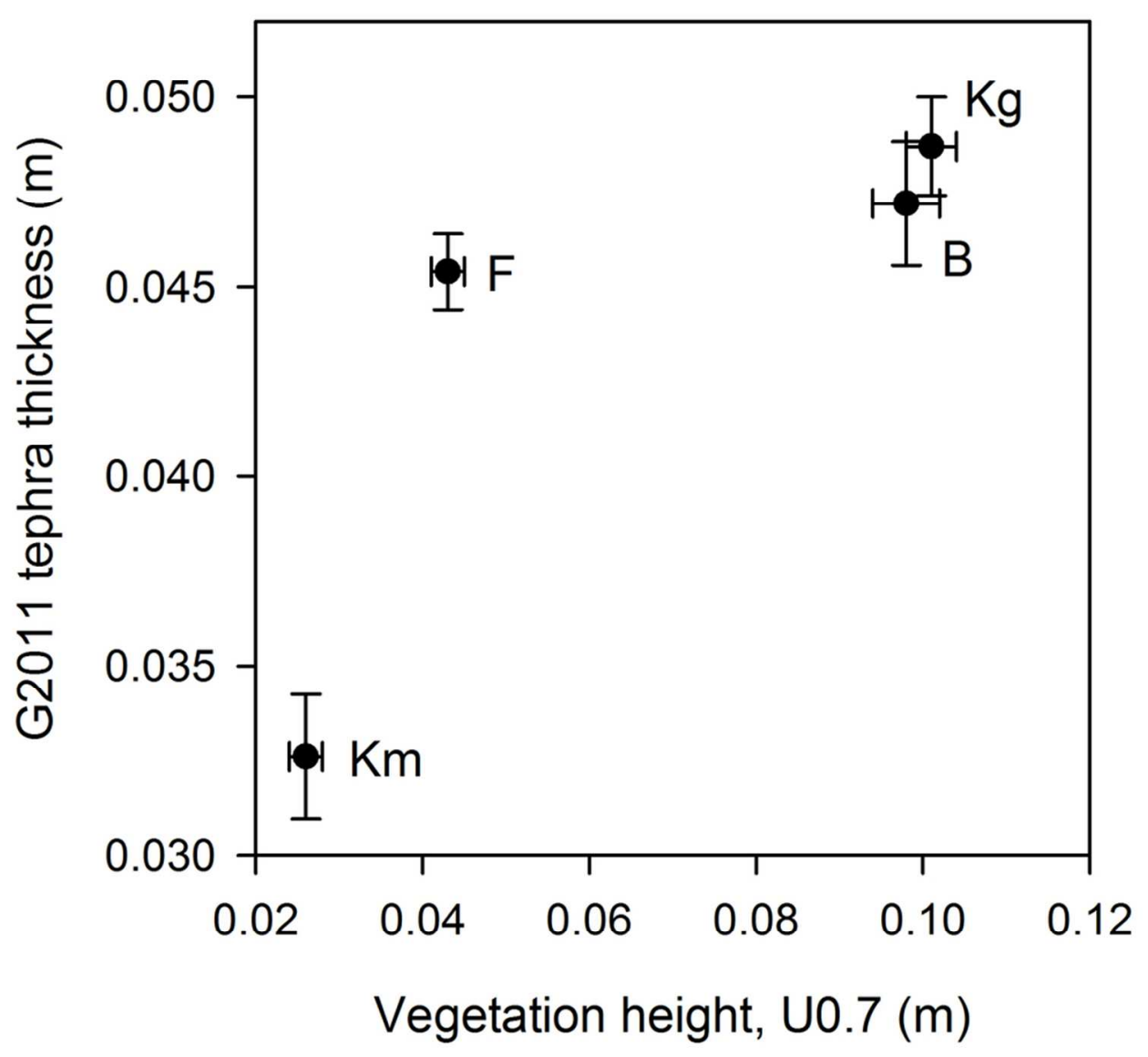

$86 \times 88 \mathrm{~mm}(300 \times 300 \mathrm{DPI})$ 